\title{
最適航路に関する考察
}

\author{
萩 原 秀 樹*.巻 島勉*
}

\section{A Study on the Optimum Ship Routes}

Hideki HAGIWARA and Tsutomu MAKISHIMA

\begin{abstract}
In this paper, we try to study optimum ship routes by simulations.

The main purposes of studies are to investigate the effect of wave prediction to the optimum route and to compare a few optimum routes which have different criterion functions.

We used Dynamic Programming for the optimization and 16200 G/T container ship was selected as a model ship.

The wave data were taken from actual daily wave charts of December in 1977.

The main results from simulations are as follows.

1. The tracks of minimum time routes may vary widely and rapidly with the daily changes of wave pattern.

2. A practical weather routing is possible if we can get accurate wave prediction having the first one-third period of the time enroute and optimum route is recalculated every day.

3. Minimum fuel consumption route has approximately the same track as minimum time route.
\end{abstract}

\section{1.はじめに}

一般に Weather Routing を有効に行なうには, 気象・海象の予測, 船の耐航性能の把握および最適化計算が, 迅速かつ正確になされねばならない。

現在, Weather Routing を実施する際の最も大きな障害は，大洋全体にわたる気象・海象の観測が不十分で あり，また予測理論も不完全なことから，気象・海象の正確な長期予測が行なえないことである。最近，静止気 象衛星 (GMS) や海洋衛星 (SEASAT) が打台上げられ, 近い将来, 気像・海象の現状把握はかなり改善され るだろうが, それでも正確な長期予測はなかなか難しいと思われる。そこで, ぞの程度の期間, 気象・海象が正 確に予測できれば，実用的な Weather Routing が可能であるかということは，一考に值する問題である。

また近年，経済的な理由から減速航海を行なう船が增えてきている。従って Weather Routing Service も単に 最短時間航路だけでなく，最小燃料消費航路をも推せえするようなケースが多くなると考元られる。最適化の評 洒対象が，航海時間から燃料消費量へと变わった場合，最適航路がぞのように変化するかというととも興味ある 問題である。

そこで著者らは，冬季の東京〜サンフランシスコ航路を航海するコンテナ船を例にとって，最適航路シミュレ ーションを行ない，上に述べたような問題について考察した。そして Weather Routing を行なう際に参考とな り得る，いくつかの結論を得たので報告する。

\section{2. 最適航路決定問題の定式化および解法}

最適航路シミュレーションに括いては, 最適化の手法として Dynamic Programming (D.P.) を用いた。以下,

* 正会員 東京商船大学（東京都江東区越中島 2-1-6） 
最適航路決定問題を数式表現して，その D.P.による解法を示す。

2.1 連続過程としての定式化

船の位置ベクトルを $\boldsymbol{X}=\left[\begin{array}{l}\varphi \\ \lambda\end{array}\right]$

$\varphi:$ 緯度 $\lambda:$ 経度

船の制御ベタトルを $U=\left[\begin{array}{l}\theta \\ P\end{array}\right]$

$\theta:$ コース $P:$ エンジン出力

船体運動ベタトルを $\boldsymbol{M}=\left[\begin{array}{c}a \\ b \\ \vdots\end{array}\right]$

$a, b, \cdots$ : 横摇れ角度, F.P. 上下加速度, 波浪縱曲げモーメント等の船体運動量

この時， $\boldsymbol{X}, \boldsymbol{U}, \boldsymbol{M}$ には，次のような拘束条件が付帯する。

と定義する。

$$
\boldsymbol{X} \in \boldsymbol{X}_{a}, \quad \boldsymbol{U} \in \boldsymbol{U}_{a}, \quad \boldsymbol{M} \in \boldsymbol{M}_{a}
$$

ただし

$\boldsymbol{X}_{a}$ ： 許容位置ベクトル（船が航行可能な海域）

$\boldsymbol{U}_{a} ：$ 許容制御ベクトル（船にとって可能な制御量）

$\boldsymbol{M}_{a}$ ： 許容船体運動ベクトル（許容しうる船体運動量）

さて, 船の速度 $\boldsymbol{V}$ は, 気象・海象と船の制御 $\boldsymbol{U}$ の関数である。もし航海中の気象・海象が, 時間と場所の 関数として確定しているならば，船の速度 $\boldsymbol{V}$ は, 船の位置 $\boldsymbol{X}$, 船の制御 $\boldsymbol{U}$ および時間 $t$ の関数として表わせ る。

$$
V=\frac{d X}{d t}=f(X, U, t)
$$

今, 時刻 $t_{0}$ に出発地 $X_{0}$ を出発して, 目的地 $X_{f}$ まで航海する船を考える。この時, 次の評価関数 $J$ を最 小にする航路を“最適航路”と呼ぶことにする。

$$
J=\int_{t_{0}}^{t_{f}} \alpha(X, U, t) d t+\gamma\left(t_{f}, t_{d}\right)
$$

ただし

$\alpha(X, U, t)$ ： 単位時間あたりの評価量

$\gamma\left(t_{f}, t_{d}\right)$ : 目的地 $\boldsymbol{X}_{\boldsymbol{f}}$ に括ける評価量

$t_{f} \quad$ ：目的地 $\boldsymbol{X}_{\boldsymbol{f}}$ に到着する時刻（末定）

$t_{a} \quad$ ：運航者の希望する到着時刻

最適化の評価対象には，航海時間，然料消買量，快適度など溙々なものが考えられるが，それらを表現するも のが， $\alpha(\boldsymbol{X}, \boldsymbol{U}, t)$ である。例えば，最短時間航路ならば $\alpha=1$ ，最小燃料消費航路ならば $\alpha=($ 単位時間あたりの 燃料消費量）と置けばよい。

また一般に，目的地における評価量 $\gamma\left(t_{f}, t_{d}\right)$ は，

$$
\begin{cases}t_{f} \geqq t_{a} \text { ならば } \gamma \geqq 0 & \text { [delay penalty] } \\ t_{f} \leqq t_{a} \text { ならば } \gamma \leqq 0 & \text { [dispatch reward] }\end{cases}
$$

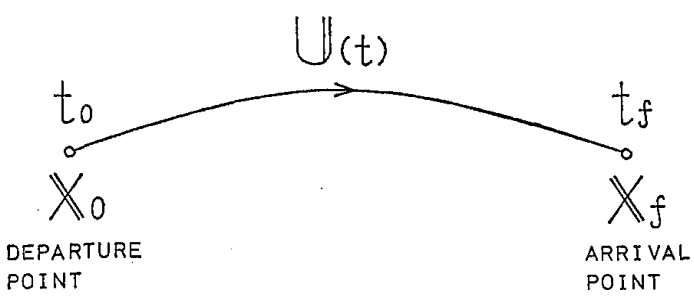

図 1 連続過程としての表現
である。

評価対象が航海時間ならば $\gamma=0$ であるが，それ以外の場合

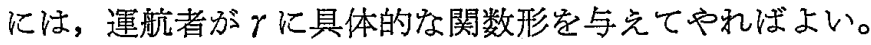
以上のことから最適航路を決定する問題は，(1) 式の拘束 条件を満たしながら，(2) 式に従って船を航走させた時，(3) 式の評価関数 $J$ を最小にするように, 制御 $U$ を時間 $t$ の 関数として決定することに帰着する。 


\section{2 離散過程としての定式化}

実際にシミュレーションを行なうには, 位置 $\boldsymbol{X}$, 制御 $\boldsymbol{U}$, 時間 $t$ を適当に離散化し, 問題を多段決定過程と して扱う方が便利である。

まず（3）式において，到着時刻 $t_{f}$ は未定なので，離散化する際に不便である。

そこで $t_{0}<t_{N}<t_{f}$ となることが確実である時刻 $t_{N}$ を適当に設定して，(3) 式を次のように变形する。

$$
J=\int_{t_{0}}^{t_{N}} \alpha(\boldsymbol{X}, \boldsymbol{U}, t) d t+\int_{t_{N}}^{t_{f}} \alpha(\boldsymbol{X}, \boldsymbol{U}, t) d t+\gamma\left(t_{f}, t_{a}\right)
$$

さて, $t_{0} \sim t_{N}$ を $N$ 等分し，

$$
\begin{aligned}
& t_{i}=t_{0}+i \Delta t \quad(i=0,1, \cdots, N) \\
& \Delta t=\left(t_{N}-t_{0}\right) / N
\end{aligned}
$$

時刻 $t_{i}$ の時の位置を $\boldsymbol{X}_{i}$, 時刻 $t_{i}$ から時刻 $t_{i+1}$ までの制御を $\boldsymbol{U}_{i}$ と書くことにし, 問題を離散的に表現す れば，(2) 式は,

$$
\boldsymbol{X}_{i+1}=\boldsymbol{X}_{i}+\boldsymbol{f}\left(\boldsymbol{X}_{i}, \boldsymbol{U}_{i}, t_{i}\right) \Delta t
$$

また，(4) 式の右辺第 2 項を $\beta\left(\boldsymbol{X}_{N}, \boldsymbol{U}_{N}, t_{N}\right)$ と書けば，評価関数 $J$ は次のように表わせる。

$$
J=\sum_{i=0}^{N-1} \alpha\left(\boldsymbol{X}_{i}, \boldsymbol{U}_{i}, t_{i}\right) \Delta t+\beta\left(\boldsymbol{X}_{N}, \boldsymbol{U}_{N}, t_{N}\right)+\gamma\left(t_{f}, t_{d}\right)
$$

ここで $\beta\left(\boldsymbol{X}_{N}, \boldsymbol{U}_{N}, t_{N}\right)$ は, 時刻 $t_{N}$ に到達した位置 $\boldsymbol{X}_{N}$ から目的地 $\boldsymbol{X}_{f}$ までのラムライン上定, 制御 $\boldsymbol{U}_{N} に$ より航走した場合の， $\boldsymbol{X}_{N} \sim \boldsymbol{X}_{\boldsymbol{f}}$ の評価量定意味する。（従 って, 制御 $\boldsymbol{U}_{N}$ はエンジン出力のみに依存する。)

従って，離散過程として最適航路を決定する問題は, (1) 式の拘束条件を満たしながら，(6) 式に従って船を航走さ せた時，（7）式の評価関数 $J$ を最小にするように，制御 $\boldsymbol{U}_{i}(i=0,1, \cdots, N)$ を決定することに帰着する。

\subsection{Dynamic Programming による解法}

$C_{n+1}\left(\boldsymbol{X}_{N-n}, t_{N-n}\right)$ を, 時刻 $t_{N-n}\left(t_{0} \leqq t_{N-n} \leqq t_{N}\right)$ の時,

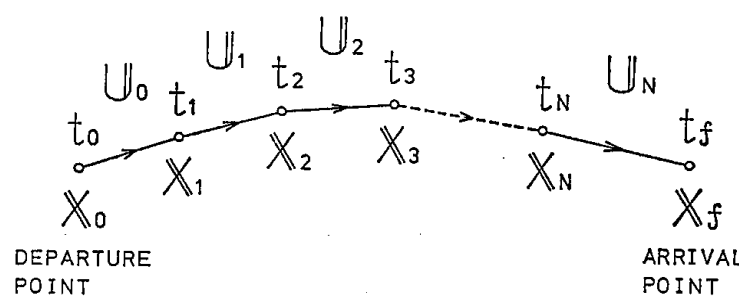

図 2 離散過程としての表現 位置 $\boldsymbol{X}_{N-n}$ から目的地 $\boldsymbol{X}_{\boldsymbol{f}}$ を目指して出発した場合の， $\boldsymbol{X}_{N-n} \sim \boldsymbol{X}_{\boldsymbol{f}}$ の最小評価量とする。

$$
C_{n+1}\left(\boldsymbol{X}_{N-n}, t_{N-n}\right)=\operatorname{Min}_{\boldsymbol{U}_{\boldsymbol{i}}}\left\{\sum_{i=N-n}^{N-1} \alpha\left(\boldsymbol{X}_{i}, \boldsymbol{U}_{i}, t_{i}\right) \Delta t+\beta\left(\boldsymbol{X}_{N}, \boldsymbol{U}_{N}, t_{N}\right)+\gamma\left(t_{f}, t_{d}\right)\right\}
$$

ただし $C_{n+1}$ の添字 $n+1$ は，制御 $\boldsymbol{U}_{i}(i=N-n, N-n+1, \cdots, N)$ による $n+1$ 段の最適化を行なうことを 表わす。

（8）式は，Bellman の最適性の原理により，次のような関数再帰方程式として表わせる。

$$
\begin{aligned}
C_{n+1}\left(\boldsymbol{X}_{N-n}, t_{N-n}\right)= & \operatorname{Min} .\left\{\alpha\left(\boldsymbol{X}_{N-n}, \boldsymbol{U}_{N-n}, t_{N-n}\right) \Delta t+C_{n}\left(\boldsymbol{X}_{N-n}\right.\right. \\
& \left.\left.+\boldsymbol{f}\left(\boldsymbol{X}_{N-n}, \boldsymbol{U}_{N-n}, t_{N-n}\right) \Delta t, t_{N-n}+\Delta t\right)\right\} \quad(n=1,2, \cdots, N)
\end{aligned}
$$

境界条件として,

$$
C_{1}\left(\boldsymbol{X}_{N}, t_{N}\right)=\operatorname{Min}_{\boldsymbol{U}_{N}}\left\{\beta\left(\boldsymbol{X}_{N}, \boldsymbol{U}_{N}, t_{N}\right)+\gamma\left(t_{f}, t_{d}\right)\right\}
$$

（10）式により $C_{1}$ を求め, 以後（9）式を用いて順次， $C_{2}, C_{3}, \cdots, C_{N+1}$ を求めることによって， $\boldsymbol{X}_{0} \sim \boldsymbol{X}_{\boldsymbol{f}}$ の 最小評価量 $C_{N+1}\left(\boldsymbol{X}_{0}, t_{0}\right)$ が得られる。そして同時に, 最適制御ベクトル $\boldsymbol{U}_{i}^{*}(i=0,1, \cdots, N)$ と最適航路 $\boldsymbol{X}_{i}^{*}$ $(i=1,2, \cdots, N)$ を決定することができる。

（9）（10)式は，様々な評洒対象を扱うことができ，また多くの拘束条件を容易に取り入れることもできる。そ してその解は，最適航路であるための十分条件を備えている。

シミュレーションでは，(9),(10) 式に基いて最適化計算を行なった。 


\section{3. シミュレーションに使用する波浪データ}

船の運航に影響を与える気像・海象には，風，波，海流，流氷，霧など様々なものがあるが，それらの中で Weather Routing を行なう際に，最も考慮すべきものは，波である。そこでシミニレーションにおいては，モデ

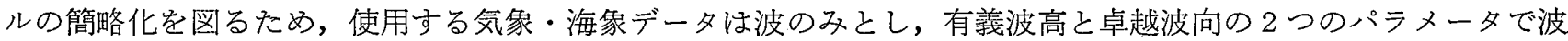
を表わすととにした。

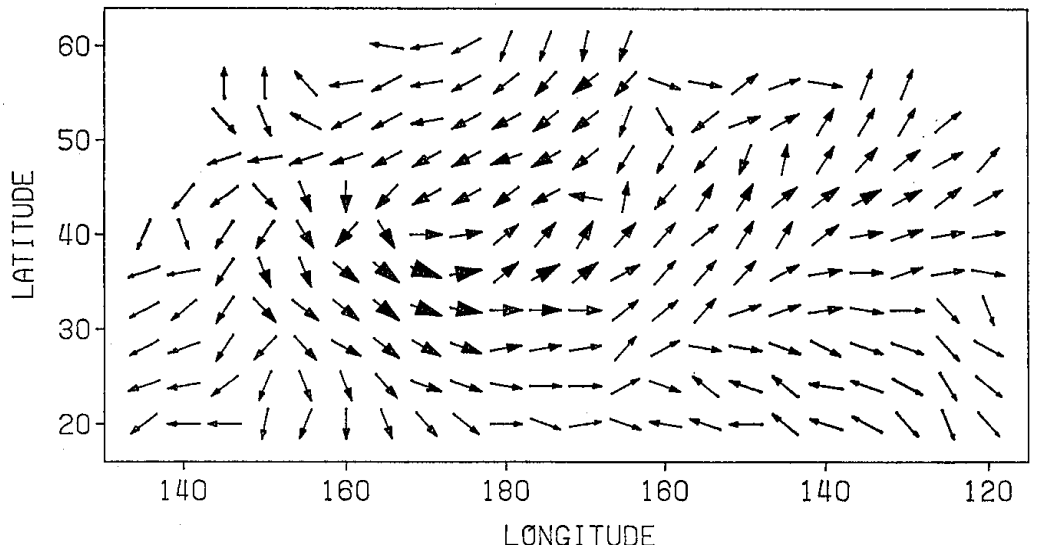

WAVE HEIGHT

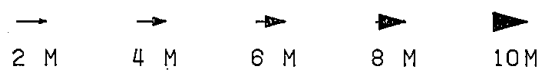

図 3 波浪データの 1 例

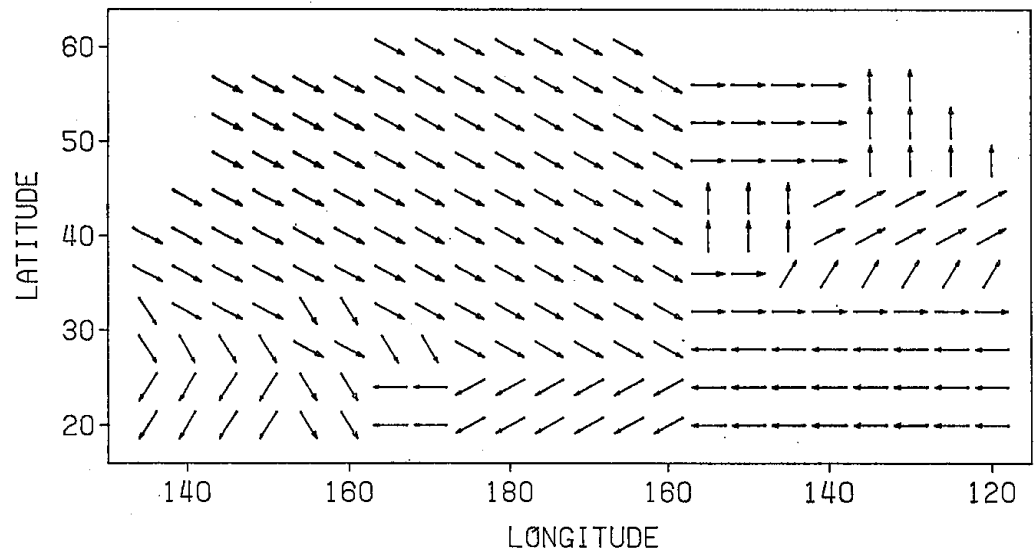

WAVE HEIGHT

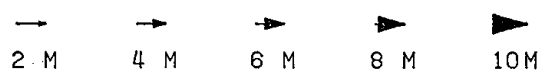

図 4 統計的な波浪データ
また実際の Weather Routing では, 当然のことながら，予想波浪図を用いる のであるが，シミュレーションでは実況 波浪図を用いた。すなわち波浪予測は必 ず的中するとして，Weather Routing を 行なったことになる。

波浪データは，有義波高については， 気像庁の外洋波浪図から読み取った。ま た卓越波向については，上記波浪図から はわかりにくいので，FNWC (米海軍艦 隊数值予報センター）の波浪図から読み 取った。

データの期間は,

1977 年 12 月 1 日 12 月 31 日 データの海域は,

$20^{\circ} \mathrm{N} \sim 60^{\circ} \mathrm{N}, 130^{\circ} \mathrm{E} \sim 120^{\circ} \mathrm{W}$

読み取りの時間間䧻は,

1 日（每日 0900 J.S.T. のもの）

読み取りの格子点間隔は,

緯度方向 $4^{\circ}$ ，経度方向 $5^{\circ}$ である。 図 3 に 1 例として，12月 12 日の波浪 データを示す。

さて，現在の波浪予測は，スペクトル 法で約 3 日間が限度であり，最適航路を 計算するにはとれ以後，適当な波浪デー タを接続しなければならない。そしてそ れには普通，類似予測（過去のデータと の相関による予測）のデータや，月別の 統計的なデータが用いられている。

シミュレーションでは，接続させる波浪データとして，1954〜1963 年の 12 月における風浪の平均值(1)学用い た。その波浪データを図 4 に示す。

\section{4. 航走させるコンテナ船の耐航性能}

シミュレーションでは，16200 G/T，175 m L $P$ P のコンテナ船（デッキ上 3 段積み）を航走させた。

このコンテナ船の波浪中での自然減速および運航限界学決定するには，細田，北沢らの研究(2),(3)を参考にし た。以下，自然減速および運航限界に関する式は，彼らの研究結果に対する近似式である。

自然減速については，短波頂不規則波中での船速を，次のような式で表わした。

$$
\begin{aligned}
& V=V_{0}(P)-m(P) \cdot f(h) \cdot g(\phi) \\
& V_{0}(P)=0.905 P^{1 / 3}
\end{aligned}
$$




$$
\begin{aligned}
& m(P)=1.4-2.8 \times 10^{-5} P \\
& f(h)=12.0\left(1.0-e^{-3.2 \times 10^{-3} h^{2.8}}\right) \\
& g(\phi)=0.8 e^{-4.1 \times 10^{-5} \psi^{2.4}}+0.2 \\
& \text { た だし }
\end{aligned}
$$

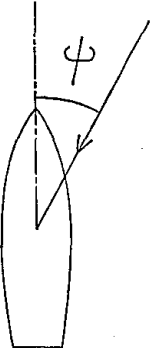

図 5 相対 波向 $\phi$

$$
V: \text { 速力 }(\mathrm{KT})
$$

$P:$ エンジン出力 (B.H.P.)

$h:$ 有義波高 $(\mathrm{m})$

$\phi$ : 相対波向 (deg.)

[船の針路之卓越波向之 のなす角]

また運航限界については，短波 頂不規則波中に和いて，F.P.上 下加速度の限界值を $0.8 \mathrm{~g}$ とし， その限界発生確率を $1 / 10^{8}$ 回に設定した。これ は，縦運動の平均周期を 7.2 秒とすれば， 2 時 間に 1 回に相当する。

本船型の運航限界には，このほ少，F.P. 海水 打ち込み，横摇れ，波浪縦曲げモーメントなど が影響するが，今回のシミュレーションでは， F.P.上下加速度のみを取り上げた。

ある波浪状態に和ける運航限界速力は，次式 により決定されるとした。

$$
\begin{aligned}
& V_{\text {limit }}=e^{0.13(q(\phi)-n)^{1.6}}+r(\phi) \\
& q(\phi)=12.0+1.4 \times 10^{-4} \phi^{2.3} \\
& r(\phi)=7.0+4.0 \times 10^{-4} \phi^{2.3}
\end{aligned}
$$

ただし $V_{\text {limit }}$ ：運航限界速力（KT)

最適航路計算において， $V>V_{\text {limit }}$ となった 場合には，運航限界を越えたとして，そのコー スとエンジン出力による探索を中止するととに した。

図 6 (a)，6(b)，6(c) に，エンジン出力が $7900,10000,12500$ B.H.P. の場合の, 速力 $V$ (実線) および運航限界速力 $V_{\text {limit }}$ (点線) 示 す。図でハッチングをほどこした部分は，運航限 界を越える領域である。

\section{5. 最適航路シミュレーション}

以上述べてきたような準備のもとに，東京〜 サンフランシスコ航路孛例にとって，最適航路 シミュレーションを行なった。

このシミュレーションでは，最適化を行なう ステージ数を 9 とし，各ステージの長さは 1 日 とした。（ただし第 9 ステージは最終ステージ なので，長さは不定である。）

また各ステージにおいて，制御 $U$ による探

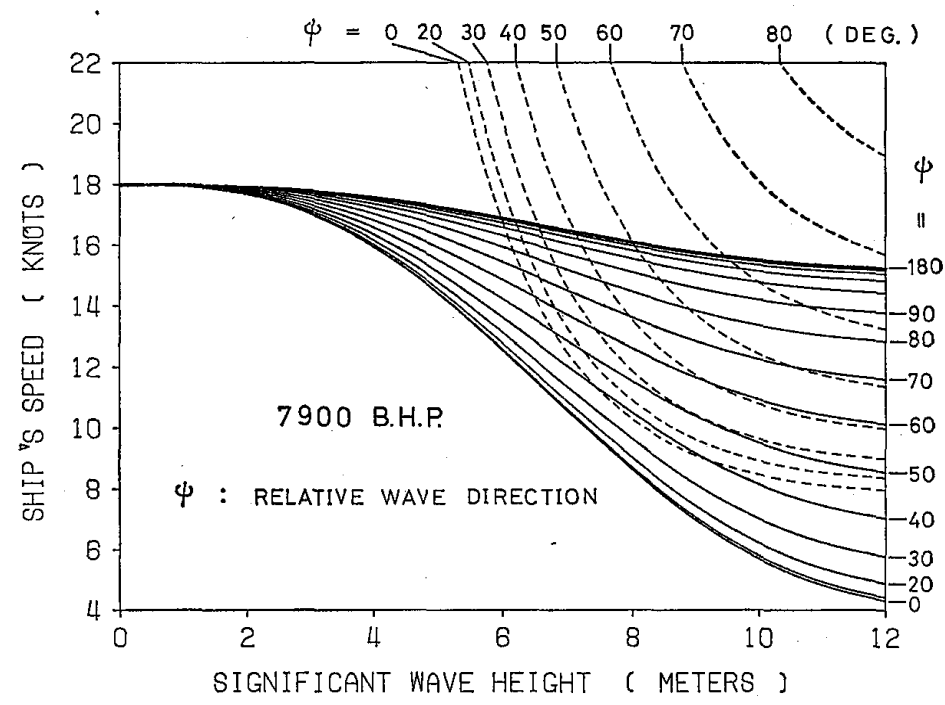

図 6 (a) エンジン出力 7900 B.H.P. の場合

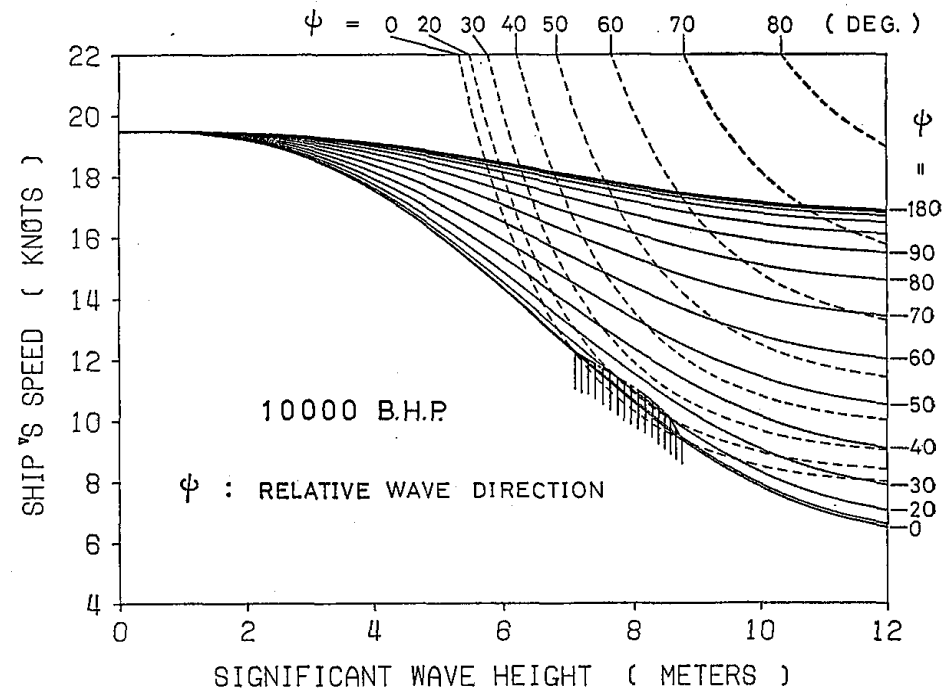

図 6 (b) エンジン出力 10000 B.H.P. の場合

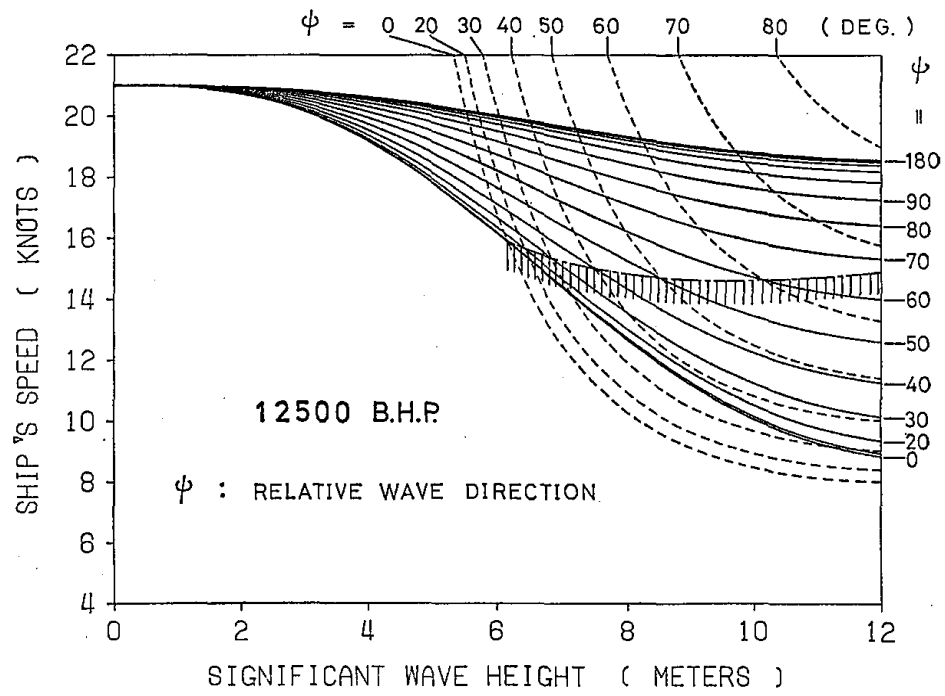

図 6 (c) エンジン出力 12500 B.H.P. の場合

図 6 短波頂不規則波中に打ける速力（実線）打よび運航 限界速力 (点線) 
索定行なうための出発点 $\boldsymbol{X}$ として，次のような格子点客設定した。

格子点の範囲： $25.0^{\circ} \mathrm{N} \sim 57.5^{\circ} \mathrm{N}, 138.0^{\circ} \mathrm{E} \sim 123.0^{\circ} \mathrm{W}$

格子点間隔: 緯度方向 $2.5^{\circ}$, 経度方向 $3.0^{\circ}$

以下, シミュレーションの結果を示し, 最適航路の特性について考察する。

5.11 日ごとの出港日に対する最短時間航路

ここでは 1 日ごとの出港日に対する 20 日間の最短時間航路を求め，その形状，航海時間，平均速力等につい て考察した。またそれらが，大洋航路誌記載の推せえ航路に比して，ぞの程度有利かということも調べてみた。 なお波浪データは，航海の全期間について，正確にわかっているものとした。

\section{1 .1 計算方法}

(9)，(10）式に扔いて,

$\alpha=1, \beta=$ (最終ステージの航走時間)， $\gamma=0, \Delta t=24$ 時間， $N=8$ として計算した。

各ステージに打ける探索は, コースについては, 格子点から目的地に到る大圈航路の初期針路の左右に, 11 通 り $\left(10^{\circ}\right.$ ごと) 行なった。また，エンジン出力については 12500 B.H.P. とし，その出力で運航限界を越えた場 合には，順次 10000 B.H.P., 7900 B.H.P. と出力を落とすことにした。

5.1 .2 結 果

12 月 1 日 20日出港の最短時間航路它, 図 7 (往航), 図 8 (復航) に示す。

図中, 点線の航路は, 大洋航路誌による推せえ航路であり, 北からベーリング海を通る航路, 大圈航路, $35^{\circ} \mathrm{N}$

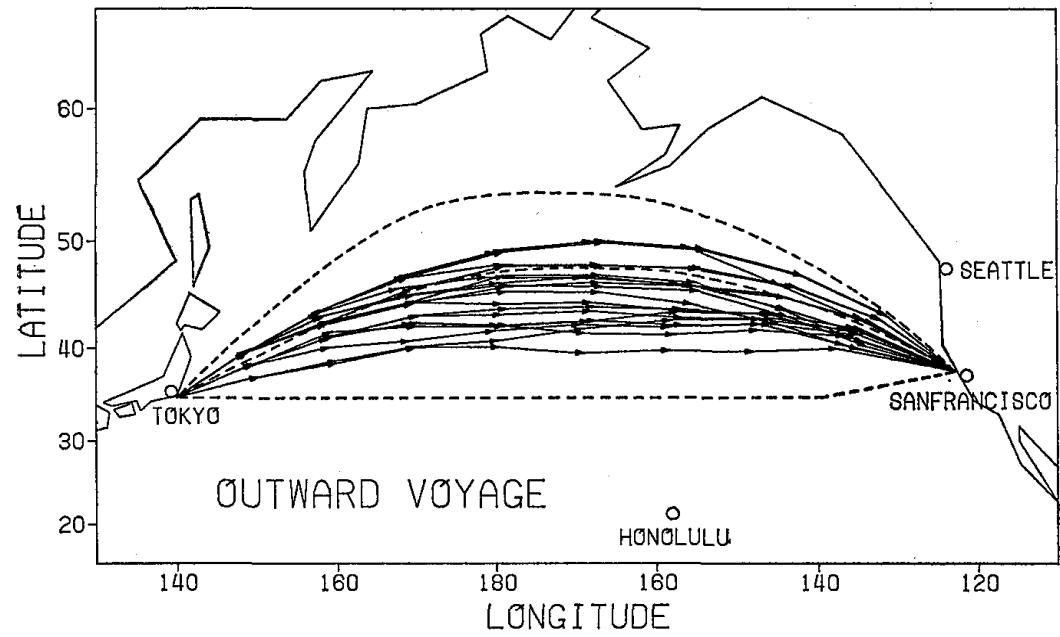

図 7 12月 1日〜20 日出港の最短時間航路（往航）

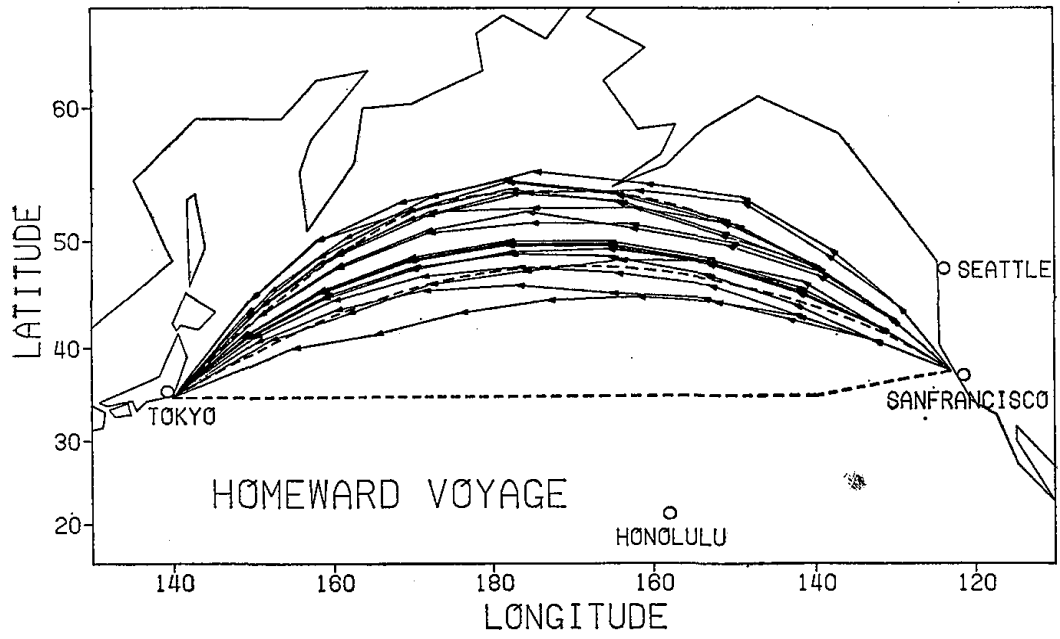

図 8 12月 1 日 20 日出港の最短時間航路（復航）
の距等圈を通る航路となっている。（以 後, 北方航路, 大圈航路, 南方航路々呼 ぶことにする。)

また，出港日に対する航海時間を図 9 (往航), 図 10 (復航) 飞, 平均速力を 図 11 (往航), 図 12 (復航) 飞, Vertex を図13 に示す。

\section{1 .3 考 察}

i）図 7, 図 8 の航跡安見ると，平均的 には, 往航では大圈より南方, 復航では 大圈より北方の航路が有利であったと言 える。また真の最短時間航路は, あまり 屈曲した形をとらないとともかかる。 ii）図 9, 図 10 見ると，北方，大圈， 南方の推せえ航路では, 航海時間の変動 幅が 1 日近くに及んでいるものがある。 また相続く出港日に対して，航海時間の 差名 10 時間近くになる場合もある。

このことから日ふの波浪パターンは， かなり大きく，また急激に変化しうるこ とがわかる。従って，ここで使用した波 浪データからは，季節別の推せえ航路な どは，あまり当てにならないと言える。 iii）一航海の平均速力を比較すれば, 各航路の波浪状態が推測できる。図 11, 図 12 を見ると，特に復航の南方航路で は平均速力の小さい航海が多く，西方か らの波が卓越していたことがわかる。 
次に 20 回の航海中，運航限界堂越えたこ とにより，エンジン出力を絞った航海の回数 を表 1 に示す。この表からも，復航の南方航 路は荒天が多く，不利であったととがわか る。

表 1 エンジン出力を絞った航海の回数

\begin{tabular}{|l|c|c|}
\hline & $\begin{array}{l}\text { OUTWARD } \\
\text { VOYAGE }\end{array}$ & $\begin{array}{l}\text { HOMEWARD } \\
\text { VOYAGE }\end{array}$ \\
\hline $\begin{array}{l}\text { MINIMUM TIME } \\
\text { ROUTE }\end{array}$ & 0 & 0 \\
\hline $\begin{array}{l}\text { NORTHERN } \\
\text { ROUTE }\end{array}$ & 3 & 1 \\
\hline $\begin{array}{l}\text { GREAT CIRCLE } \\
\text { ROUTE }\end{array}$ & 2 & 4 \\
\hline $\begin{array}{l}\text { SOUTHERN } \\
\text { ROUTE }\end{array}$ & 0 & 10 \\
\hline
\end{tabular}

また最短時間航路は, 往航, 復航ともエン ジン出力を絞った航海がなく，波浪状態の良 い海域を通ったことがわかる。

iv）図 13 を見ると，最短時間航路のVertex は, 往航, 復航とも約 $10^{\circ}$ に及ぶ幅で変動し て扣り，その変化も急激な場合がしばしばあ る。特に, 復航の出港日 12 月 11 日と 12 日の航海では，出港日が 1 日違うだけで， Vertex の差が $10^{\circ}$ 以上にも及んでいる。

これは，最短時間航路が波浪パターンの变 化に対し，かなり敏感であること示すもの で, Weather Routing には正確な長期波浪子 測が不可欠であることがわかる。

5.2 波浪予測期間を $0,1,2, \cdots$ (days) した場合の最短時間航路

5.1 では，航海中の波浪データがすべてわ かっているものとしたが，波浪予測を行なえ る期間には限度がある。

ここでは波浪予測期間を $0,1,2, \cdots$ (days) と変えた場合，最短時間航路がどのように変 化するかを調べた。そしてどの程度の期間， 正確な波浪予測が得られれば，実用的な Weather Routing が可能であるが考察し た。

\section{2 .1 計算方法}

航海中においても，波浪予測データは 1 日 ごとに更新される。そこで波浪予測データが 更新されるたびに，その時の船位を新たに出

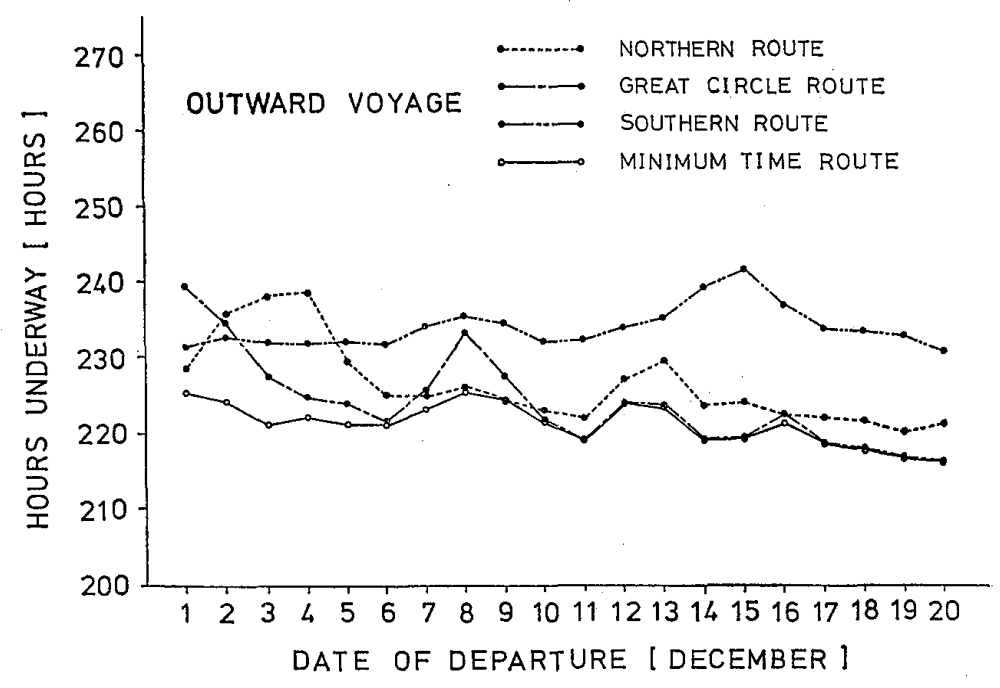

図 9 出港日に対する航海時間（往航）

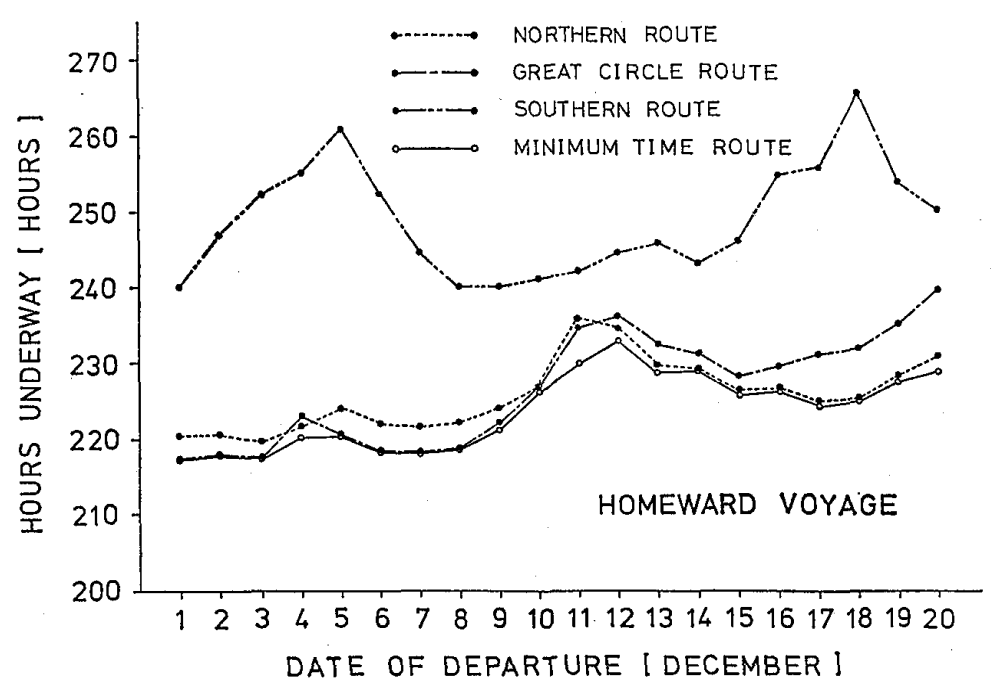

図 10 出港日に対する航海時間（復航）

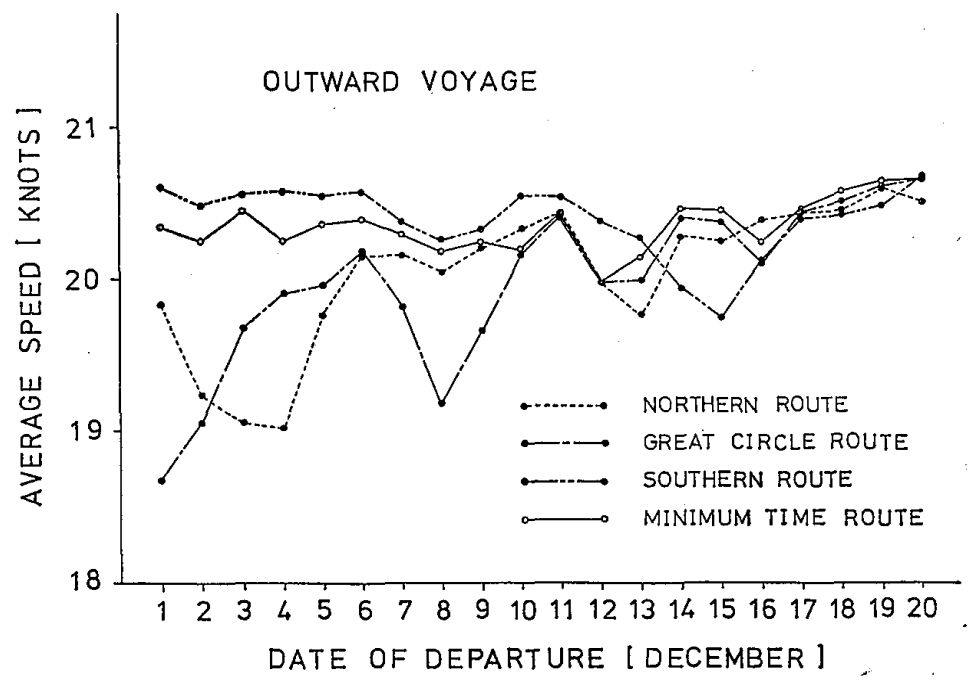

図 11 出港日に対する平均速力（往航） 


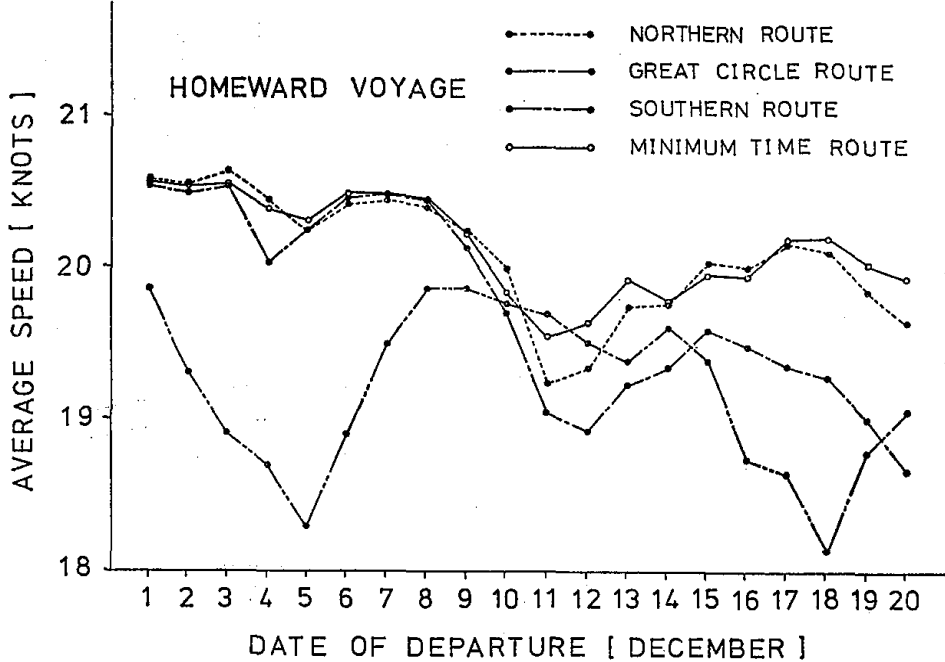

図 12 出港日に対する平均速力（復航）

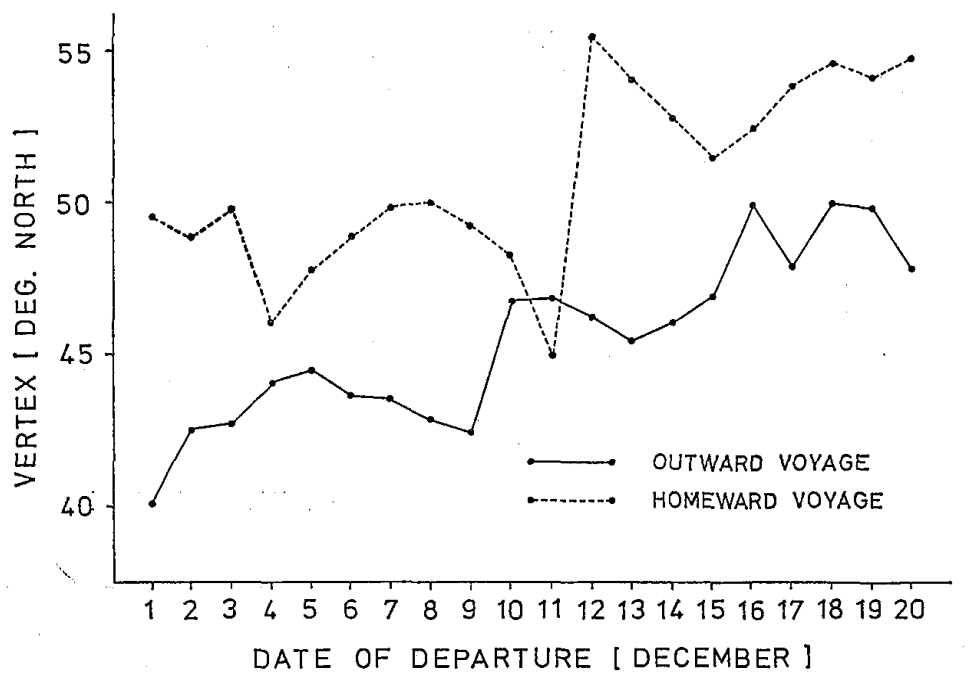

図 13 出港日に対する最短時間航路の Vertex

発点として, 最短時間航路を再計算するように した。

従って，(9)，(10) 式に打いて $N$ は, 出港 時の計算で 8, その後 1 日ごとの再計算では, $7,6, \cdots, 0$ とした。 $\alpha, \beta, \gamma, \Delta t$ は， 5.1 子同様 である。また，コース和よびェンジン出力の探 索についても， 5.1 と同様である。

なお，予測期間以後の波浪データには，図 4 の統計データを用いた。

\section{2 .2 結 果}

波浪予測期間をいろいると变光た場合の最短 時間航路を，図 14 (往航，出港日 12 月 1 日） および図 15（復航，出港日12月18日）に示 す。図中, 点線は $5.1 て ゙$ 求めた真の最短時間航 路であり，各航路に付してある数字は，その航 路を計算した際の波浪予測日数である。

また，波浪予測期間に対する航海時間を，図 16 に示す。

\section{2 .3 考 察}

i) 図 14, 図 15 を見ると，往航，復航ともに 波浪予測を 3〜4 日行なえば，ほぼ真の最短時 間航路に近い航路が得られている。また図 16 からも，3〜4 日の予測期間があれげ，航海時 間は十分減少することがわかる。

$$
\text { シミュレーションに使用したさンテナ船は， }
$$

約 10 日間で太平洋を横断するから，“波浪予測 が正確で，航海時間の約 $1 / 3$ 程度の予測期間が あれば，実用的な Weather Routing が可能で ある。”と言える。

ii) このシミュレーションの結果には, 最適化 計算を出港時だけでなく，航海中も波浪

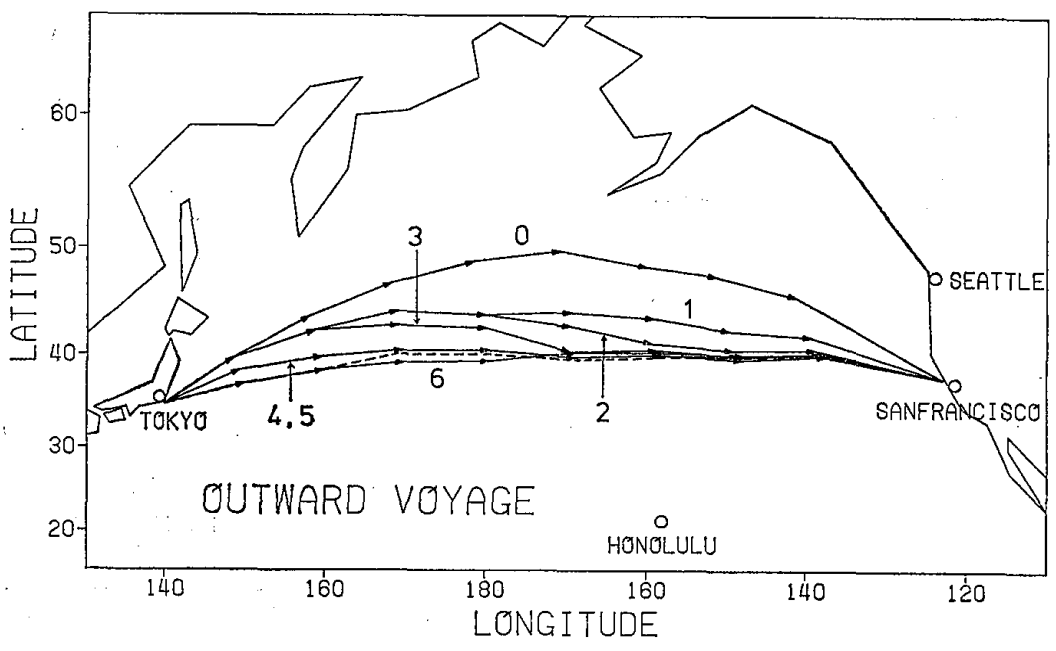

図 14 波浪予測期間安いろいろと変元た場合の最短時間航路 （往航，出港日 12 月 1 日）
予測データが更新されるたびに行なった ということが，大きく貢献している。

現在の Weather Routing Service は, 出港時に推せえ航路を与え，以後はその 船を follow して，新たに荒天が予測さ れる場合には，推せえ航路を変更すると いう方式が多い。

このような方式では，毎日更新される 波浪予測データを，十分活用していると は言えない。これからの Weather Routing は，ここで行なったように，波浪予 測データを最大限利用すべきである。 iii）このシミュレーションでは, 波浪 予測が正確であることを前提とした。し 
かし，現在のスペクトル法による波浪予 測では，せいぜい1〜2 日間しか十分な 精度を維持できない。

従って，その後 1 週間程度の波浪予測 を, 適当な方法（例えば類似予測）で行 なう必要がある。そしてその波浪予測の 精度が, Weather Routing の成果に大き く影響すると言える。

\section{3 最小燃料消費航路}

近年，多くの船が経済的な理由から減 速航海安行なっている。それらの船は， ある決められた期日までに目的地に着く ことを前提として，できるだけ燃料を節 約しようとしているわけである。

ここでは到着日時を指定して，その日

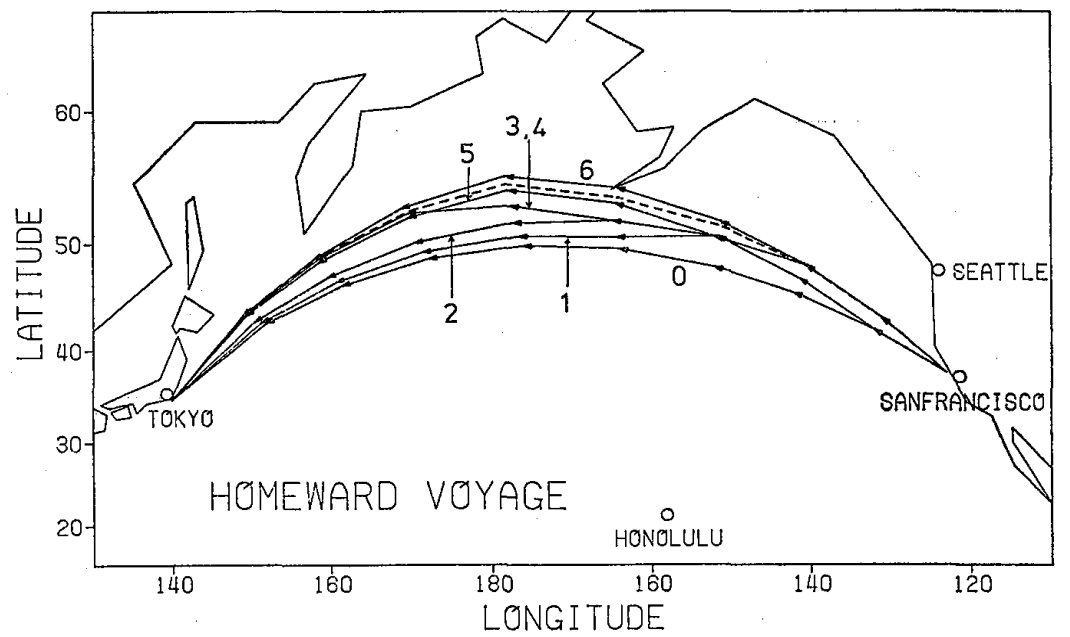

図 15 波浪予測期間をいろいろと変えた場合の最短時間航路 （復航，出港日 12 月 18 日）

時までに目的地に着くことを条件とする最小燃料消費航路を求 め，最短時間航路との比較を行なった。な报浪データは 5.1 そ同栐, 航海の全期間について，正確にわかっているものとし た。

\section{3 .1 計算方法}

(9)，（10）式において, $\alpha=(1$ 時間あたりの燃料消費量) $\beta=($ 最終ステージに括ける燃料消費量)

$\left(\gamma=0 \quad\left(t_{f} \leqq t_{d}\right)\right.$

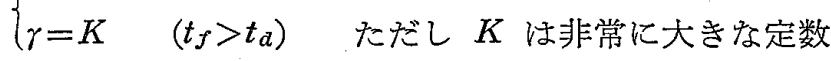
$\Delta t=24$ 時間, $N=8$

として計算した。

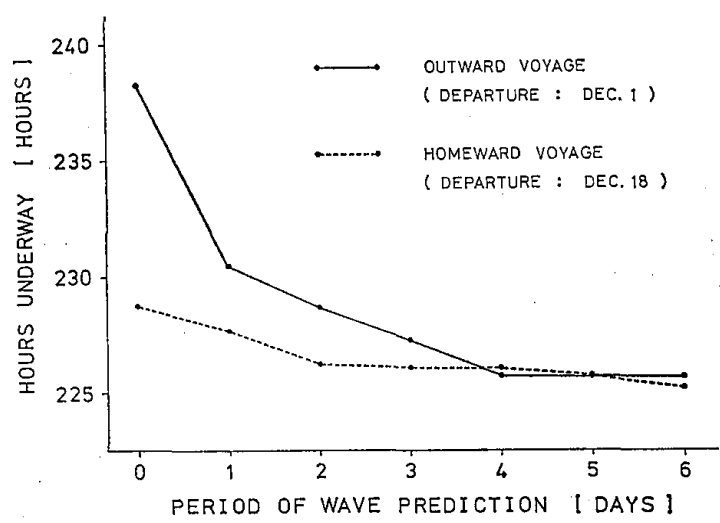

図 16 波浪予測期間に刘する航海時間

各ステージに打ける探索は, コースについては, 格子点から目的地に到る大圈航路の初期針路の左右に, 7 通 り（15ごと）行なった。ンジン出力については，12500，10000，7900 B.H.P.の 3 通りとした。 な执燃料消費量は，3 通りのエンジン出力に対し，3.5, 2.8,2.2 ton/hour とした。

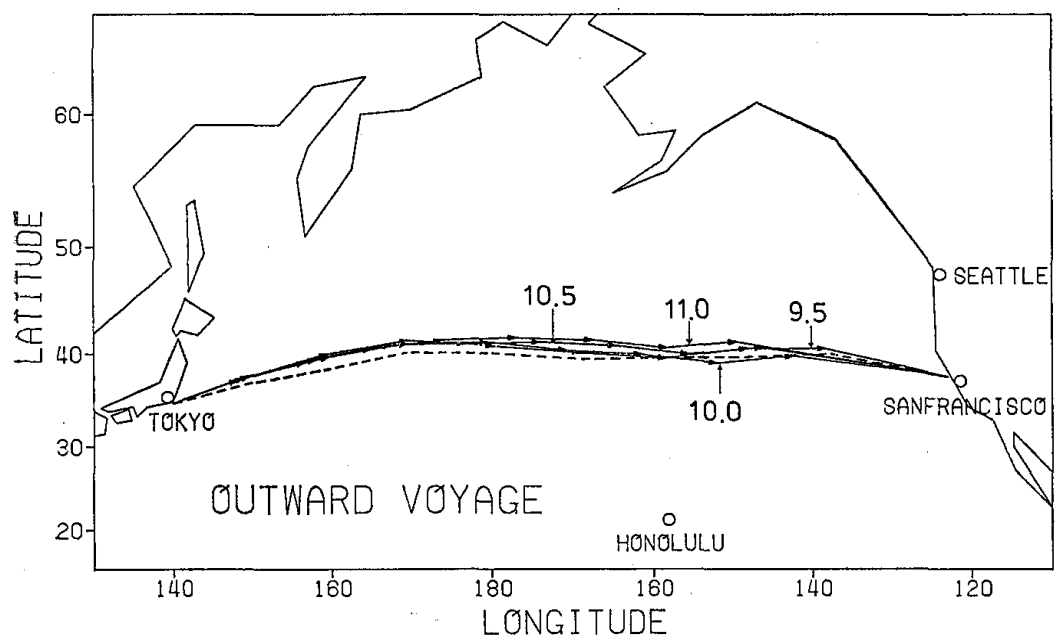

図 17 到着期限をいろいろと変えた場合の最小燃料消費航路 （往航，出港日 12 月 1 日）

\section{3 .2 結 果}

到着期限色出港後，9.5，10.0，10.5， 11.0 日とした場合の最小燃料消費航路 を, 図 17 (往航, 出港日 12 月 1 日), 図 18 (復航, 出港日 12 月 18 日) に示 す。図中，点線は 5.1 で求めた最短時間 航路であり，各航路に付してある数字 は，到着期限定わしている。

また，航海時間に対する燃料消費量の 関係を, 図 19 に示す。

\section{3 .3 考 察}

i）図 17, 図 18 の航跡を見ると，最小 燃料消費航路は，到着期限を 1 2 日変 えた程度では，さ注ど変わらないことが わかる。また各航路は，点線で示した最 


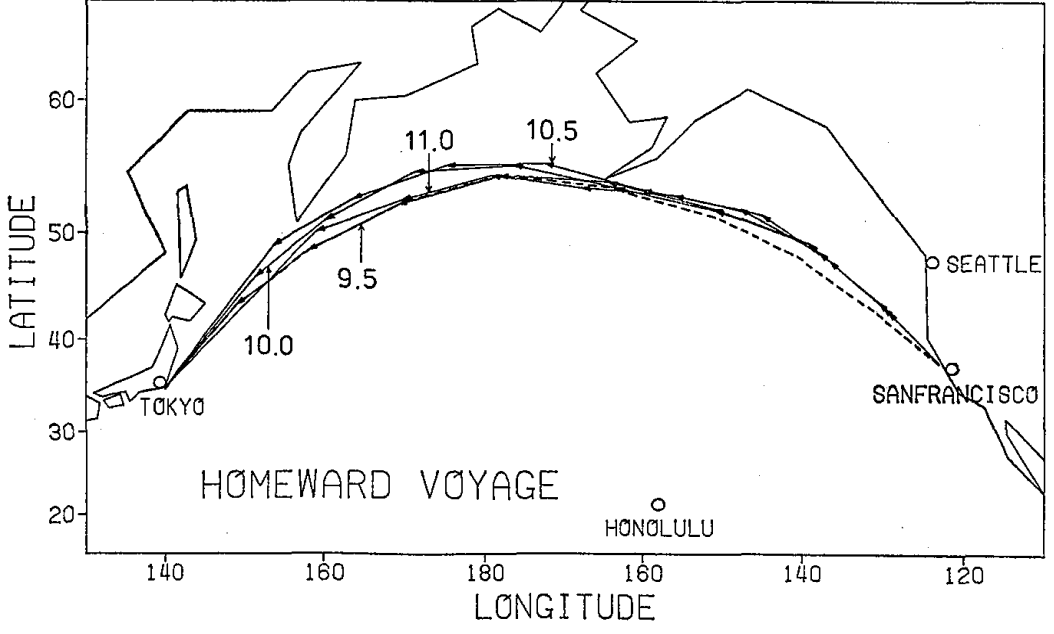

図 18 到着期限をいろいろと変えた場合の最小燃料消費航路 （復航，出港日 12 月 18 日）

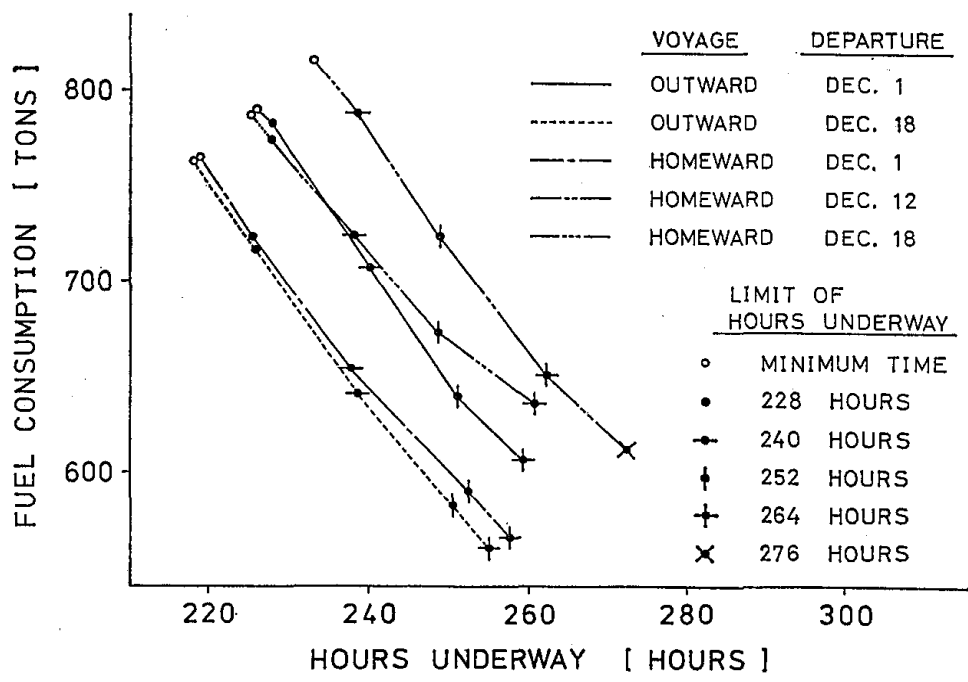

図 19 最短時間航路および最小燃料消費航路の航海時間に 対する燃料消蒷量

短時間航路から，あまり大きくは離えて いない。

往って，“到着期限をあまり遅らさな い限り（波浪パターンに，あまり大きな 差異が出て来ない範囲において)，最小 燃料消費航路は，最短時間航路乙一致す る。すなわち，燃料をもっとも節約する には，最短時間航路上を，エンジン出力 を適当に絞りながら航走すればよい。” と言える。

ii）図 19 から，到着期限を早めるにつ れて，燃料消費量は急速に増大すること がわかる。

また，同じ到着期限でも，出港日によ って（すなわち波浪パターンの違いによ って), 然料消費量には大きな差がでることも わかる。

iii）エンジン出力と波高，相対波向の間に は，明確な相関は見い出せなかった。

最小燃料消費航路を決定する際には，航海 全体における波浪パターンが関与し，またコ 一スも制御変数の 1 つとて，荒天域を避け るように㗢く。従って，単にエンジン出力と 波浪状態のみに着目しても，その関係は単純 ではないわけである。

\section{6. ま め}

以上，最適航路決定問題定定式化して，そ の Dynamic Programming による解法を示し， 最適航路シミュレーションを行なって，最適 航路の特性について考察した。

シミュレーションの結果を要約すると，次のようになる。

（1）最短時間航路は，波浪パターンの变化によって，かなり大きく，また急激に变動する。従ってWeather Routing には，正確な長期波浪予測が不可欠である。

（2）波浪予測が正確で，航海時間の約 $1 / 3$ 程度の予測期間があれば，実用的な Weather Routing が可能であ る。

（3）最小燃料消費航路は，到着期限をあまり遅らさない限り，最短時間航路と一致する。

今回のシミュレーションでは，実沉波浪図を用いたので，波浪予測の精度については考慮しなかった。今後は， 予想波浪図を用いたシミュレーションを行ない，予測精度が最適航路に及ぼす影響を調查するつもりである。

最後に，本研究を行なうにあたり，多くの御指尊を頂いた，東京商船大学須田教授，杉崎・大津・堀籠助教授 および貴重なデータを提供して下さった，気象庁，OCEANROUTES（株），日本郵船（株）の方々に深謝致し ます。 
参考 文 献

(1) Y. Yamanouchi and A. Ogawa: Statistical Diagrams on the Winds and Waves on the North Pacific Ocean, Papers of Ship Research Institute, Supplement No. 2, March 1970

（2）日本造船研究協会第 125 研究部会：超高速コンテナ船の耐航性に関する研究, 研究資料 No. 188, 1974 年 3 月

（3）北沢孝宗, 他： コンテナ船の波浪中での限界速度，日本造船学会論文集，第 138 号，1975 年 12 月

(4) H. T. Chen, E. G. Frankel, A. E. Fiore and H. Carleton: Optimization of Ship Weather Routing, Ship Operation Automation II, 1976

（5） 杉崎昭生： 最適航法の基礎研究 I V, 日本航海学会誌, 第 $34 \cdot 35 \cdot 36 \cdot 38 \cdot 39$ 号, $1965 \cdot 1966 \cdot$ $1967 \cdot 1968$

（6）黑井昌明，他：理論的限界速度を用いた最適航路計算 1〜4, 関西造船協会誌，第 $147 \cdot 154 \cdot 156$ ・ 159 号, $1973 \cdot 1974 \cdot 1975$

（7）日本造船学会：耐航性に関するシンポジウム I・II，1969・1977

（8）日本航海学会: 船舶の荒天運航に関するシンポジウム, 1973

(9) 尾形克彦: ダイナミックプログラミング, 培風館, 1973

（10）Julius T. Tou (中村・伊藤・松尾 共訳)：現代制御理論，コロナ社，1966

\section{質 疑 応答}

今津隼馬：最小燃料消費航路が最短時間航路とほぼ一致していると言われたが，波浪パターンの影響が大きい とすれば，一概に言えないのでは。

萩原秀樹：シミュレーションでは，同一の出港時刻について，最小然料消費航路と最短時間航路と老比較しま した。波浪パターンの影響は，出港時刻が同一で，航海時間が多少異なる場合よりも，出港時刻が異なる場合 に大きく現われると思われます。

榊 正三: 太平洋航路においては，海流の影響が非常に大きいと思いますが，その点は如何ですか。

萩原秀樹：確かに海流は大きなファクターとなりますが，今回のシミュレーションでは，モデルの簡略化を図 るために考虑しませんでした。今後はデータとして, INPUTしていくつもりです。

井上篤次郎： 針路を制御するわけですが，その進路のとり方は，連続量か離散量か。また離散量の場合，何度 ずつに選んだか。

萩原秀樹：離散量です。探索は，設定した格子点から目的地に到る大圈航路の初期針路の左右に，10ずつ，11 通り行ないました。 